\title{
Discussion of the Euthanasia
}

\author{
Wang Chen \\ Zhengzhou Shuqing Medical College , Zhengzhou Henan, China, 450064
}

\section{Keywords: Euthanasia, Terminally III, Ethical}

\begin{abstract}
This article is based on a suppositional case, the core of the article is discussed about the euthanasia. The discussion from both of legal side and ethical side and draw a conclusion that under the background of the case, euthanasia is acceptable. But we must pay attation to that this case occurred in state Montana, in which the Supreme Court of Montana hold that under Mont.Code.Ann. $\S 45-2-211$, a terminally ill patient's consent to physician aid in dying can constitute a statutory defense to a charge of homicide against the aiding physician.
\end{abstract}

Case: Elizabeth Bouvia, who now lives in Helena, Montana, had cerebral palsy from birth and was quadriplegic, her whole body paralyzed except for her right hand and a few muscles allowing minor face and head movements. She also suffered from degenerative arthritis, which, despite her paralysis, caused constant pain that could not be relieved entirely even with doses of morphine. She is dependent on tube feedings, but her attempts to refuse them have generated such angst for her and her caregivers, she is unwilling to refuse any longer. Elizabeth is terminally ill, but it is unclear when she will die. In fact, she has already outlived the most optimistic predictions. Elizabeth would like the opportunity for affirmative assistance to die with dignity (e.g., physician aid in dying) at the time of her choosing. The following discussion will stand on the supporting of her request.

\section{I. legal analysis:}

In the case Baxter v. Montana , Robert Baxter was terminally ill and suffered from a variety of debilitating symptoms, he "wanted the option of ingesting a lethal dose of medication prescribed by his physican and self-administered at the time of [his] own choosing.". The Supreme Court of Montana hold that under Mont.Code.Ann. § 45-2-211, a terminally ill patient's consent to physician aid in dying can constitute a statutory defense to a charge of homicide against the aiding physician.

In the present case, Elizabeth Bouvia "had cerebral palsy from birth and was quadriplegic, her whole body paralyzed except for her right hand and a few muscles allowing minor face and head movements. She also suffered from degenerative arthritis, which, despite her paralysis, caused constant pain that could not be relieved entirely even with doses of morphine." She is dependent on tube feeding and terminally ill. So the fact applies the case Baxter. And we must not ignore the fact that Elizabeth Bouvia also lives in Helena, Montana.

"The Terminally Ill Act, in short, confers on terminally ill patients a right to have their end-of-life wishes followed, even if it requires direct participation by a physician through withdrawing or withholding treatment.” Base on these words, as a terminally ill patient, Elizabeth Bouvia has the right to has her end-of-life wish followed.

Same as in the case Baxter, there exists a counterargument that physician cannot help Elizabeth Bouvia dying by active move the feeding tube away because this action seems like aggravated assault. We can also get the defense from the case Baxter that:

"[I]f the State prosecutes a physician for providing aid in dying to a mentally competent, terminally ill adult patient who consented to such aid, the physician may be shielded from liability pursuant to the consent statute. This consent defense, however, is only effective if none of the statutory exceptions to consent applies. Section 45-2-211(2), MCA, codifies the four exceptions:

Consent is ineffective if: (a) it is given by a person who is legally incompetent to authorize the conduct charged to constitute the offense; (b) it is given by a person who by reason of youth, mental disease or defect, or intoxication is unable to make a reasonable judgment as to the nature or 
harmfulness of the conduct charged to constitute the offense; (c) it is induced by force, duress, or deception; or (d) it is against public policy to permit the conduct or the resulting harm, even though consented to."

Since Elizabeth Bouvia was 25 years old, bright, articulate, mentally competent and she want to move the tube away by her own truly desire, the first three exceptions are not applied. In the forth exception, "against public policy" always be identified as "sheer physical aggression that breaches public peace and endangers others", but the act of a physician taking away a feeding tube from a terminally ill patient is not comparable to the violent, peace-breaching conduct to violate public policy. At the same time, the courts declined to "deem consent ineffective when defendants directly commit blatantly aggressive, peace-breaching acts against another party."

Similar in present case, although physician may take the feeding tube away, it doesn't mean he directly involved in the final decision or the final act. Physician can connect the tube again at any time when Elizabeth Bouvia needs. The final act is Elizabeth Bouvia's own act that starving herself to death. So the physician's act doesn't apply the forth exception.

Base on the discussion above, Elizabeth Bouvia has a right to have her end-of-life wishes followed under The Terminally Ill Act. Also the physician who move the feeding tube away from Elizabeth Bouvia can constitute a statutory defense to a charge of homicide against him under the case law of Baxter.

\section{Ethical analysis:}

In the present case, on the layer of ethical analysis, should be discussed from both sides of Elizabeth Bouvia and physician.

On the side of Elizabeth Bouvia, the most important issue is whether she has the right to choose euthanasia?

As a commonplace, everyone should has the right to decide how her live to go. People "are endowed by their Creator with certain unalienable Rights, [including]...Life” So "[p]eople have an interest in making important decision about their lives in accordance with their own conception of how they want their lives to go." The human life is full of choice, in every minute person should make a decision that what to do in the next minute. These choices constitute the meaning of the life. When the individual making the decision, she has weight the balance between the suffering and happiness. Individuals have a tendency to choose the way of life that can enlarge the happiness. As personal happiness cannot be felt by anyone else, this choice can only be select by herself. In the present case, Elizabeth Bouvia choose asking for moving feeding tube away that base on her own feeling. Anyone else cannot enforce her to choose a way that she never wanted. When she make this decision, it means that she prefer death with dignity more than living longer.

In the case, Elizabeth Bouvia is terminally ill, although she has already outlived the most optimistic predictions and it is unclear when she will die, but she has lay down on the bed for 25 years. Nobody else can imagine how suffering she is. Now, she has even suffered a more suffering pain that she must bear a feeding tube inserting inside her body. She should and must own the right to decide whether living depends on the tube. It may be the last thing she can decide by herself. Why not we give her the last choice to maintain her minimum dignity?

In another side, Elizabeth Bouvia needed continuous care, but her family would not oblige and she had no job, no income, no home, and no hope of getting help except through public assistance. She is pathetic and hopeless. When Pandora closed the Pithos, she just kept the "Hope" inside. Human is living with the motivation of following the hope. When Elizabeth Bouvia lost all of the hope in her life, her last hope is death with dignity. Why not we respect her?

"If we are in a position to relieve the severe suffering of another without excessive cost to ourselves, we have a duty to do so. To refuse would be cruel, inhumane, and wrong." This conclusion can also be applied as "[i]f a competent, hopelessly ill patient in unrelieved agony requests help to be put out of his misery, we may have a duty to bring about his death." As bioethicist Dan W.Brock says "euthanasia may be the only release from their otherwise prolonged suffering and agony.” So we should agree with the Elizabeth Bouvia's choice on her side. 
At the same time, we should take it in argument that whether physician taking the feeding tube away is ethical and moral.

In the case, Elizabeth Bouvia hope physician can help her to move the feeding tube away. If the physician move the tube away, this manner would constitutes an passive voluntary. "Passive euthanasia is allowing someone to die by not doing something that would prolong life. It includes removing a patient's feeding tube..."Passive euthanasia "is legal provided certain conditions are met”.

Although the patient has the right to decide whether to die or live, we also should take it into argument that whether physician's helping is ethical and moral.

In the popular opinions, physician's duty is to prolong the life of the body. "The intentional termination of the life of one human being by another- mercy killing- is contrary to that for which the medical profession stands” But when we face to the real case, this opinion may be not applied.

It is true that the physician's duty is to prolong the life of the body, but the underlying meaning of this duty is to make patient living in a comfortable condition. What is the aim of life that we desired? It is the quality of life rather than the time of life. Keeping patient living in the suffering condition is same as harming him. "The justification for [physician's withholding treatment] is that the patient is in terrible agony, and since he is going to die away, it would be wrong to prolong his suffering needlessly." Although it is wrong to termination of the life of patient, it is more harmful to enforce the terminally ill patient to bear the suffering needlessly.

In medical ethics, the duty of physician should not just be defined as to prolong the patient's life. It should be defined as to make patient living comfortable and dignity. The physician can give the patients the suggestions of medical care but they must respect the patients' choices.

In present case, as discussed before, taking the feeding tube away doesn't mean directly kill the Elizabeth Bouvia. It is just an action under the consent of the patient. If Elizabeth Bouvia changed her choice, as she feel starving is more suffering than die with dignity, she can order physician to connect the feeding tube immediately. Whether taking away or connecting again are all base on the respecting to the patients. Neither of these two actions contrary to the duty of physician. Even more, these actions make patient more comfortable for they can make the decision by their own desire freely.

In conclusion, both from the sides of legal and ethical analysis, Elizabeth Bouvia has a right to refusing feeding tube for death with dignity. Physician's withdrawing treatment is not illegal and unethical.

\section{References}

[1] Baxter v. Montana, MT DA 09-0051, 2009 MT 449, 5.

[2] Lewis Vaughn, Bioethics Principle, Issues, and Cases, Oxford University Press(2010),58.

[3] The Declaration of Independence of the Thirteen Colonies

[4] Lewis Vaughn, Bioethics Principle, Issues, and Cases, Oxford University Press(2010), 530,531

[5] Hastings Center Report 22.2

[6] James Rachels, Active and Passive Euthanasia. 